M.: The languiages of slav. culture (Languiage. Semiotic. Culture) [in Russian].

8. Ruchjevskaja E. (2011).The works of different years. Coll. of articles in 2 v. / T. II. About vocal music / V.V. Goryachikh (Ed.). SPg. : Composer Sanct-Petersburg. [in Russian].

9. Sukchomlinov I. (1976). To problem of interpretation of EtudesTableaux of Rachmaninov. Skill of musician-perfomer. Moscow : Soviet composer. Issue 2. [in Russian]. Pp. 147-186.

10. Florensky P. (2005) Ikonostas. Moscow. [in Russian].

11. Economtsev Ioann, (1992), igumen. Orthodox. Visantia. Russia. Coll. of articles. Moscow: "Christian literature". [in Russian].

УДК 782.1

DOI https://doi.org/10.31723/2524-0447-2020-30-2-15

Тетяна Петрівна Книшова

ORCID: 0000-0003-4699-5464

заслужена артистка України, доцент, приват-професор кафедри сольного співу

Одеської національної музичної академії імені А. В. Нежданової tatyana.knyshova@gmail.com

\title{
ХРИСТИЯНСЬКІ АСПЕКТИ ПОЕТИКИ «БОРИСА ГОДУНОВА» М. МУСОРГСЬКОГО ТА ЇХ УТІЛЕННЯ В СЦЕНІЧНІЙ ВЕРСІЇ А. ТАРКОВСЬКОГО
}

Мета роботи - виявлення християнського складника поетики «Бориса Годунова» М. Мусоргського й особливостей іï інтерпретаиіі в режкисерській постановочній версії А. Тарковського. Методологія дослідження спирається на інтонаційну концепцію музики, а також на міждисииллінарний та історико-культурологічний підходи, що дають змогу виявити духовно-релігійне підгрунтя музичного театру М. Мyсоргського, зокрема його опери «Борис Годунов». Наукова новизна роботи полягає в подальшому поглибленні та збагаченні уявлень про поетику оперної творчості М. Мусоргського й особливості ї̈ інтерпретації в умовах духовно-етичних шукань європейської культури кіния XX століття. Висновки. «Борис Годунов» М. Мусоргського являє собою унікальний твір європейського музичного театру ХІХ століття. Численні

(C) Книшова Т. П., 2020 
авторські та постановочні редакції твору, активно затребувані в сучасній виконавській практиці, виявляють послідовний рух авторської музично-драматургічної думки від «моноопери» до «історичної народної музичної драми», а також органічність взаємодії позначених жанрових компонентів поетики названого твору. Водночас образно-семантична специфіка опери базується на духовно-релігійних, «храмових»константах, які становлять трунт російської музичної класики, що виявляється й у місиях розгортання оповідання, зосереджених на території при храмі, і на суттевій драматургічній ролі персонажків, причетних до агіографічної традиції (иаревич Димитрій, Пимен) $і$ вищих проявів національної релігійності й духовності (Юродивий), і в затребуваності в поетиці твору семантики молитви, дзвону, що виявляють літургійно-містеріальний контекст як образу Бориса Годунова, так і поетико-інтонаційних особливостей опери М. Мусоргського загалом як «драми совісті» (Н. Тетеріна). Позначений духовно-релігійний контекст виявився затребуваним в історичному бутті твору в кінці XX століття, а також співвідносним з духовно-естетичними настановами творчості А. Тарковського. Його режисерська концепція постановки опери М. Мусоргського формувалася на перетині засвоєння духовних констант російської культури та їх творчого переосмислення. Останне позначилося на доповненні символічного «ряду» твору семантичними ознаками ікони «Трійця», маятника, мапи Росії, а також на духовному поглибленні образу Юродивого.

Ключові слова: російська опера ХIX століття, музичний театр М. Мусоргського, «Борис Годунов» М. Мусоргського, релігійно-етична проблематика «Бориса Годунова» М. Мусоргського.

Knyshova Tetiana Petrivna, Honored Artist of Ukraine, Associate Professor, Private Professor at the Department of Solo Singing of the Odessa National A. V. Nezhdanova Academy of Music

Christian aspects of the poetics of "Borys Godunov" by M. Mussorgsky and their embodiments in the stage version of A. Tarkovsky

The purpose of the work - revealing the Christian component of the poetics of "Boris Godunov" by M. Mussorgsky and the peculiarities of its interpretation in the director's staged version of A. Tarkovsky. The methodology of the work relies on the intonational concept of music, as well as on interdisciplinary and historical and cultural approaches that allow to identify the spiritual and religious foundations of the musical theater of M. Mussorgsky, including his opera "Boris Godunov". The scientific novelty of the work consists in the further deepening and enrichment of ideas about the poetics of the operatic creativity of M. Mussorgsky and the peculiarities of its interpretation in the context of the spiritual and ethical searches of European culture at the end of the twentieth century. Conclusions. "Boris Godunov" by M. Mussorgsky is a unique work of the European musical theater of the 19 th century. Numerous author's and staged versions of the opera, actively demanded in modern performing practice, reveal the consistent movement of the author's musical and dramatic thought from "mono-opera" to "historical 
folk musical drama", as well as the organic interaction of the indicated genre components of the poetics of the said work. At the same time, the figurative and semantic specificity of the opera is based on the spiritual and religious, "temple" constants that form the basis of Russian musical classics, which is also manifested in the places where the action develops, concentrated on the parish territory; and on the essential dramatic role of the characters involved in the hagiographic tradition (Tsarevich Dimitri, Pimen) and the highest manifestations of national religiosity and spirituality (Foolishness for Christ); and in the demand in poetics for the work of the semantics of prayer, bell ringing, revealing the liturgical and mystery context of both the image of Boris Godunov and the poetical and intonational features of the opera by M. Mussorgsky as a whole as a "drama of conscience" (N. Teterina). The indicated spiritual and religious context turned out to be required in the historical existence of the work at the end of the 20th century, and also correlated with the spiritual and aesthetic attitudes of A. Tarkovsky's work. His directorial concept for staging an opera by M. Mussorgsky was formed at the intersection of mastering the spiritual constants of Russian culture and their creative rethinking. The latter affected the addition of the symbolic "series" of the work with semantic signs of the Trinity icon, the pendulum, the map of Russia, as well as the spiritual deepening of the image of the Foolishness for Christ.

Key words: Russian opera of the XIX century, musical theater of M. Mussorgsky, "Boris Godunov" of M. Mussorgsky, religious and ethical issues of "Boris Godunov" of M. Mussorgsky.

Кнышова Татьяна Петровна, заслуженная артистка Украины, доцент, приват-профессор кафедры сольного пения Одесской национальной музыкальной академии имени А. В. Неждановой

\section{Христианские аспекты поэтики «Бориса Годунова» М. Мусоргского и их претворение в сценической версии А. Тарковского}

Цель работы - выявление христианской составляющей поэтики «Бориса Годунова» М. Мусоргского и особенностей ее интерпретации в режиссерской постановочной версии А. Тарковского. Методология исследования опирается на интонационную концепцию музыки, а также на междисииплинарный и историко-культурологический подходы, позволяющие выявить духовно-религиозные основания музыкального театра М. Мусоргского, в том числе его оперы «Борис Годунов». Научная новизна работы состоит в дальнейшем углублении и обогащении представлений о поэтике оперного творчества М. Мусоргского и особенностях ее интерпретации в условиях духовно-этических исканий европейской культуры кониа XX столетия. Выводы. "Борис Годунов» М. Мусоргского являет собой уникальное произведение европейского музыкального театра ХІХ столетия. Многочисленные авторские и постановочные редакции оперы, активно затребованные в современной исполнительской практике, выявляют последовательное движение авторской музыкально-драматургической мысли от «монооперы» до «исторической народной музыкальной драмы», а также органичность 
взаимодействия обозначенных жанровых компонентов поэтики названного сочинения. Одновременно образно-семантическая специфика оперы базируется на духовно-религиозных, «храмовых» константах, составляющих основание русской музыкальной классики, что проявляется и в местах развития действия, сосредоточенных на прихрамовой территории; и на существенной драматургической роли персонажей, причастных к агиографической традиции (иаревич Димитрий, Пимен) и высших проявлений национальной религиозности и духовности (Юродивый); и в востребованности в поэтике произведения семантики молитвы, колокольного звона, выявляющих литургийно-мистериальный контекст как образа Бориса Годунова, так и поэтико-интонационных особенностей оперы М. Мусоргского в иелом как «драмы совести» (H. Тетерина). Обозначенный духовно-религиозный контекст оказался затребованным в историческом бытии произведения в конце XX столетия, а также соотносимым с духовно-эстетическими установками творчества A. Тарковского. Его режиссерская концепция постановки оперы М. Мусоргского формировалась на пересечении освоения духовных констант русской культуры и их творческого переосмысления. Последнее сказалось на дополнении символического «ряда» произведения семантическими признаками иконы «Троица», маятника, карты России, а также на духовном углублении образа Юродивого.

Ключевые слова: русская опера ХІХ столетия, музыкальный театр М. Мусоргского, «Борис Годунов» М. Мусоргского, религиозно-этическая проблематика «Бориса Годунова» М. Мусоргского.

Актуальність теми дослідження. М. Мусоргський - одна 3 визначних постатей світового музичного театру. Його творчість - предмет великого інтересу не тільки вокалістів-виконавців, а й музикознавців, культурологів, а у XX столітті режисерів-постановників, що реалізують на світових оперних сценах сучасні версії тлумачення поетики його музичного театру. Сукупний досвід вивчення спадщини цього автора щоразу відкриває нові «герменевтичні кола», духовно-смислові глибини й багатовимірність його творчого генію, актуального як для культурно-історичних реалій другої половини XIX століття, так і для сучасності. На думку М. Сабініної, «удивляючись у трагічні колізії минулого, Мусоргський судом вищої моральності судить і минуле, і сьогодення, провидить майбутнє батьківщини, що загрожує нечуваними потрясіннями» [14, с. 219]. Сказане співвідносно й з оперою «Борис Годунов», сценічна доля якої на рубежі XX-XXI століть ознаменувалася двома знаковими постановками, здійсненими під керівництвом видатних кінорежисерів сучасності - О. Сокурова, а також А. Тарковського. Останньому вдалося вті- 
лити в роботі не тільки багатовимірність оперного шедевру М. Мусоргського, а й духовно-етичні шукання свого сучасника, спрямовані на дослідження драми людської свідомості, моральної відповідальності за весь світ, що єднають творчу діяльність геніїв різних епох і визначають актуальність теми представленої статті.

Аналіз досліджень і публікацій останніх десятиліть виявляє інтерес, що зростає, до творчої спадщини й особистості М. Мусоргського. Фундаментальні дослідження його творчості, представлені в роботах Г. Хубова [19], Е. Фрід, Р. Ширінян, М. Сабініної [14], І. Лапшина [7], В. Протопопова [13], можна доповнити науковими розвідками останніх десятиліть, серед яких суттєве місце посідають праці Р. Берченка [2], Л. Жуйкової [4], а також дисертаціями та супутніми публікаціями О. Михайлової [9; 10], Н. Тетеріної [18], І. Гури [3], Н. Серьогіної [15], що виявляють семантичну багатозначність його музично-театральної творчості, зокрема жанрово-інтонаційної специфіки «Бориса Годунова». Проте показово, що духовно-релігійний складник музичного театру М. Мусоргського, його «храмова константа» (А. Луніна) поряд з «історизмом художнього мислення» цього автора лише недавно стали предметом мистецтвознавчих, музикознавчих [8; 12], а також оригінальних режисерсько-сценічних узагальнень [1; 16], що виявляють безмежність духовно-етичного «всесвіту» композитора та потребують його подальшого дослідження.

Мета дослідження - виявлення християнського складника поетики «Бориса Годунова» М. Мусоргського й особливостей iii інтерпретації в режисерській постановочній версії А. Тарковського. Методологія роботи спирається на інтонаційну концепцію музики, а також на міждисциплінарний та історико-культурологічний підходи, що дають змогу виявити духовно-релігійне підгрунтя музичного театру М. Мусоргського, зокрема його опери «Борис Годунов».

Наукова новизна роботи полягає в подальшому поглибленні та збагаченні уявлень про поетику оперної творчості М. Мусоргського й особливості їі інтерпретації в умовах духовно-етичних шукань європейської культури кінця ХX століття.

Виклад основного матеріалу. Творча особистість М. Мусоргського, його духовно-релігійний складник при всій різноманітності наукових розвідок, присвячених цьому автору, поки 
залишаються предметом дискусій і припущень, оскільки предметом дослідження в цьому разі стає духовний світ автора, котрий він завжди оберігав від сторонньої уваги. А. Луніна констатує, що «релігійно-моральна тема творчості М. Мусоргського в обговоренні досить складна, тому що все, що стосувалося віри й внутрішньої «сакральної» сторони життя композитора, ним приховувалося. Уривчасті, сумбурні, суперечливі міркування про Божественне, що іноді зустрічаються в епістолярній спадщині композитора, картину релігійних переконань Мусоргського чи ледь розкривають. I хоча I. Лапшин указує на еволюцію поглядів Мусоргського від релігійно-морального зацікавлення й захоплення Іоганом-Каспаром Лафатером до безвір'я або, точніше, до віри в доктрину дарвінівського вчення про походження людини, питання його внутрішньої віри так і залишається невирішеним» [8, с. 97].

Згадуваний цитованим автором І. Лапшин, досліджуючи внутрішній світ М. Мусоргського, фіксує також увагу на певній парадоксальності його світобачення, у якому дивним чином поєднувалося сполучення «здатності до розуміння та художнього співпереживання чужої релігійності з великою дозою особистого скепсису» [7, с. 317]. Аналізуючи далі погляди М. Мусоргського на життя, людину та долю всього людства, автор констатує їх зв'язок із трагічним образом смерті та його песимістичним сприйняттям. На його думку, релігійність композитора $є$ «релігійністю хворої душі», яка, у свою чергу, $\epsilon$ «ареною вічної боротьби Бога з дияволом» [7, с. 319], породжуючи тим самим і світ духовних страждань своїх героїв і їхнє прагнення до духовної досконалості.

Позначений скепсис водночас межував у свідомості композитора з глибоким інтересом до світу православної культури. Як уважає Н. Серьогіна, «містичні погляди в листах Мусоргського проявляються якраз улітку 1872 року під час завершення другої редакції «Бориса» і на самому початку роботи над «Хованщиною». С. Тишко бачить можливі витоки містичних поглядів Мусоргського в читанні літератури про російський розкол, книг про Серафима Саровського...» [15, с. 67].

Проте, незважаючи на певні протиріччя його духовних переконань і відзначений багатьма дослідниками скепсис, для більшості нащадків творча постать М. Мусоргського сприймається передусім на рівні «митця християнської культури». «О. Бенуа пов'язує релігійний початок творчості композитора 
3 трагізмом як його першопричиною: «Мистецтво Мусоргського не було б таким народним, таким зворушливим, таким релігійним, якби воно не було «виплаканим». Г. Свиридов розцінював спадшину Мусоргського як «апологію православ'я», «розмову з Богом» [3].

Позначена духовно-релігійна якість $є$ показовою для більшої частини творчого спадку композитора. Історизм та акцентування соціальних суперечностей суспільного життя в М. Мусоргського завжди сусідять зі звертанням до Вічного, Сакрального, Надбуттєвого. У «Хованщині» це символічно відтворено в темі церковного розколу, що визначає духовно-історичні долі Русі протягом багатьох останніх століть. У «Картинках з виставки» - це всесвіт культур різних часів і національно-історичних традицій, увінчаний у фінальній п’єсі дзвоном і стилізацією церковного православного співу, що символізують глибинні духовні витоки російської культури та європейської культури загалом. Опера «Борис Годунов» також стає яскравим утіленням позначеної духовної «домінанти» творчості композитора.

Цей твір має унікальну історію та навіть сьогодні існує в багатьох сценічних версіях-редакціях. Як пише О. Михайлова, що досліджує першу авторську редакцію «Бориса Годунова» М. Мусоргського (1869), «важко знайти інший музичний шедевр XIX століття, який викликав би стільки наполегливих, різночасових спроб замінити оригінали «кращими», «більш сучасними» текстами і стільки зусиль повернутися до першоджерел» [9, с. 3]. У сценічній практиці сьогодення однаково затребуваними є всі різноманітні авторські версії цього спектаклю, що робить його унікальним твором світового оперного мистецтва, що розкрив багатогранність генія М. Мусоргського. Фіксуючи увагу на жанрових метаморфозах авторських редакцій «Бориса Годунова», що позначили рух творчої думки композитора від «моноопери» (перша редакція) до «історичної народної музичної драми» (друга редакція та іiі варіанти), Н. Тетеріна констатує, що «перехід від тенденції «мікроісторичної концепції драми совісті царя Бориса» до тенденції «макроісторичної концепції драми совісті російського народу» знаменує собою процес грандіозної еволюції в мисленні композитора-драматурга» [18, с. 34].

Подібний унікальний музично-сценічний досвід, активно затребуваний у сучасній постановній практиці, свідчить про 
яскраво виражену новаційність опери М. Мусоргського, що не має аналогів у європейському музичному театрі XIX століття. «Не декларуючи оперної реформи, композитор, по суті, здійснив реформу, яка не поступається вагнерівській, а для Росії - і більш перспективну. «Борис» поєднав доти непоєднуване. У ті часи опера ще не здійснювала замахи пильно аналізувати внутрішній світ великої реальної особистості, тобто зробитися в повному розумінні слова психологічною драмою, а не драмою любові, ревнощів, насильницької розлуки» [14, с. 256].

Сказане багато в чому визначає також і жанрову специфіку «Бориса Годунова» М. Мусоргського, яка, за влучним спостереженням М. Сабініної, $\epsilon$ «монодрамою, упровадженою в широку багатопланову історичну дію» [14, с. 259], і що, додамо, водночас базується на духовно-релігійних константах, які становлять грунт музичної класики російської культури, їі літургійний смисл з часів М. Глинки.

Дія названої опери композитора при всій іiі масштабності й історичній зумовленості все ж є зосередженою на певному «образно-просторовому контексті», що частіше всього пов'язаний із прихрамовою територією [9, с. 21]. «Храм, монастир, собор є не тільки місцем проведення обрядово-ритуальних дійств, це семантично й функціонально значимі топоси. Церква й біляцерковний простір - це хронотопи небесно-божественного царства, символ живого втілення ідеї соборності, знак святості. Згідно з висновками Т. Антипової: «Соборна площа Московського Кремля засобами архітектурної символіки втілювала ідею споконвічного кругообігу життя російських царів. В Успенському соборі - їх вінчали на царство, в теремах і палатах <..> вони жили, в Архангельському соборі $<\ldots>$ вони знаходили вічний спокій» [8, с. 97]. Серед «просторово-храмових одиниць», де відбуваються кульмінаційні події оперного оповідання, фігурує Чудов монастир, де й за часів Бориса Годунова зберігається пам'ять про царевича Димитрія, а також зароджується зухвалий план Самозванця. Один із суттєвих моментів драми - протистояння Бориса та народу пов'язаний із собором Василя Блаженного.

Духовна аура та символізм позначених місць (за винятком Третього («польського») акту) також визначає причетність учасників дії до їх сакральної сутності. На думку А. Луніної, «основна «храмова» над-ідея розкривається в хорових 
епізодах - хорі ченців-пустельників I дії, хорі схими IV дії й хорі калік перехожих першої картини Прологу, які в контексті сюжетнодієвого ряду опери сприймаються як певні позачасові символи небесного, божественного, позамежного. Хори - це реальне втілення Небесного Храму на землі, свого роду концентрат святості - об’єктивна субстанція Ідеального. За ступенем драматургічної значимості їх можна співвіднести 3 хорами давньогрецької трагедії, що коментують, роз'ясняють дію й дають моральну оцінку подіям» [8, с. 99].

Останнє зауваження дослідниці є дуже важливим, оскільки паралелі між історичною драмою М. Мусоргського та античним театром показові не тільки для трактування масових хорових сцен, а й для вибудовування образу головного героя Бориса Годунова, який В. Павлінова порівнює з Едипом-царем Софокла. «Асоціації породжує централізація дії навколо драми совісті царя, пов'язаної зі стражданнями народної маси...» [12, с. 124].

Окрім цього, в опері фігурують персонажі, безпосередньо пов'язані з духовними традиціями російської культури. До таких зараховуємо царевича Димитрія, що представлений в опері відповідною лейттемою та агіографічними оповіданнями про нього в монологах Пимена та Шуйського. Як докір совісті, привід, що неодноразово нагадує про себе, цей образ з'являється в драматичні моменти духовних страждань Бориса Годунова, обумовлюючи містеріальні аспекти поетики цього спектаклю. Показово, що в першій редакції «Бориса Годунова» драматургічний конфлікт вибудовувався саме навколо протиставлення образів Бориса і святого Димитрія [9, с. 14].

Ще однією фігурою, безпосередньо причетною до духовного світу та його цінностей є Пимен. «Він є втіленням божественного світла, досягнутого шляхом молитви, поста, крайньої аскези. Він залучений до об'єктивної Духовної даності й в опері охарактеризований як «Муж правды и совета, муж жизни безупречной» (слова Шуйського (IV дія, друга картина)). Пимен - це символічний образ «князя церкви» (Б. Асаф'єв), який неупереджено оцінює всі події» [8, с. 99].

Героєм, що символічно окреслює власне національно-релігійну якість російської православної культури, є образ Юродивого, що практично не має аналогів у західноєвропейському музичному театрі XIX століття. Він уособлює собою найвищій прояв релігійності, простоти, совісті та є істотою 
«не від світу цього», яка ніби споглядає Небесні світи із землі, а реальний світ тлумачить як арену боротьби світла і тьми, добра і зла, про що свідчить текстово-інтонаційна символіка його пророчих пісень-плачів. Додамо також, що цей вельми значимий в ідейно-драматургічній специфіці твору персонаж стає також та об'єктом особливої уваги театральних режисерів сучасності, у тому числі й А. Тарковського (див. нижче).

Подібного роду героя знаходимо в опері-міраклі Ж. Массне «Жонглер Богоматері», створеної вже на початку XX століття згідно з духовними шуканнями «релігійного відродження», показового й для культури Франції, що в цей період активно живилася також і творчим надбанням російської культури. Певна новаційність жанрової специфіки цього твору Ж. Массне, що формувалася на перетині традицій, власне музичного театру та міракля, багато в чому зумовлена також якостями головного героя - жонглера Жана, що суттєво відрізнявся від інших персонажів європейського (у т. ч. й французького) музичного театру, де зазвичай панували сильні, яскраві особистості, спроможні протистояти долі, боротися за свої ідеали, почуття тощо. Головний герой опери Ж. Массне - бідний жонглер, що належав до когорти «універсальних артистів» $[17$, с. 74$]$ і водночас до «вбогих духом», що втілювали ідеал справжнього духовного життя.

Повертаючись до твору М. Мусоргського, відзначимо, що духовно-християнська сутність поетики «Бориса Годунова» виявляється не тільки в персонажах-носіях сакральних ідей, а й у їхніх антиподах, якими є Самозванець, а також Варлаам і Місаїл. «Самозванець Лжедимитрій є не тільки пародійно-карнавальним антиподом образа Бориса, а й полярно-негативним відбиттям Світлого Лику царевича Димитрія. Він розстрига-відшепенець, який своїм зазіханням на ангелоподібний образ царевича Димитрія потоптав свята святих - віру в Бога, істину, святість». Аналогічним чином «Варлаам і Місаїл уміло «жонглюють» своїми масковим амплуа, виявляючи себе згідно із ситуацією то в одному, то в іншому уособленні. Якщо бродяжна природа - це їхня природна сутність повною мірою, що яскраво розкриється в «Сцені під Кромами» (третя картина IV діi), то, перебуваючи в такому статусі, їм не потрібно ховатися й хитрити із самими собою. Амплуа «старців смиренних» - це їхнє личинкове обличчя» [8, c. $100-101]$. 
Позначена духовно-символічна специфіка поетики «Бориса Годунова» М. Мусоргського стала визначальною й у трактуванні образу іiі головного героя. Традиційним місцем у порівнянні його тлумачення в однойменних творах О. Пушкіна та М. Мусоргського стала констатація домінування державотворчих якостей у першого й акцентуація «трагедії совісті» в другого. Показово, що вирішальна роль духовно-етичного фактору в трактуванні образа Бориса виявила свого часу не тільки позначену вище християнську позицію композитора («релігійність хворої душі»), а й особливості світосприйняття його сучасників і нащадків. О. Михайлова констатує, що «на рубежі XIX-XX століть відбувається «переоцінка цінностей»: усе більше істориків доходить висновку про невинність Бориса в смерті Димитрія, високо оцінюють роль цього царя в істоpiï Росіï» [9, с. 8]. Б. Асаф'єв афористично визначив сутність цього персонажа так: «... людина 3 хворою совістю, а не цар Борис» $[14$, с. 255]. Подібне його сприйняття характерне й для виконавської концепції цього образу у Ф. Шаляпіна, якого приваблювала в ньому передусім «психологічна драма, саме «драма совісті», яка на рубежі XIX-XX століть стала однією 3 найважливіших тем російської літератури та російського театру. Муки Бориса як покарання за злочин викликали у Ф. Шаляпіна співчуття, жалість і симпатію» [6, с. 86]. Відзначимо також, що акцентування саме теми «совісті» як сутності морального переживання становило також один із показових духовно-етичних напрямів творчої діяльності А. Тарковського, що вже 80-ті роки XX століття здійснив оригінальну постановку оперного шедевру М. Мусоргського.

Причетність образа Бориса Годунова до духовно-християнського підгрунтя твору в опері розкривається поступово. Автор послідовно простежує «процес пробудження й посилення в душі Бориса святості, його тяги до Світла, прагнення очистити совість, знайти опору у вірі, примиритися з Богом $<\ldots>$ Шлях пізнання Борисом духовної істини пролягає через душевні страждання, від зовнішньої сакральності до внутрішньої, з поступовим убуванням першої й посиленням другої» [8, с. 99]. Відповідно до логіки оповідання, злочин, здійснений ним, - у минулому, тоді як реальні події твору виявляються зосередженими (особливо в першій редакції опери М. Мусоргського) на муках совісті й каятті. Його життєвий шлях, обмежений подіями опери, розгортається на межі 
між буттям історичним і містеріальними проявами духовного світу, являючи в кінцевому підсумку повчальну історію поступового духовного преображення грішника, що викликає також певні паралелі з деякими героями творів Ф. Достоєвського [7, с. 320-322].

Молитва супроводжує найважливіші етапи царювання Бориса, а також сцену смерті. 3 іншого боку, іiі семантичне наповнення посилено символікою дзвону, що являє собою ще один «храмовий зріз» у драматургічній концепції драми М. Мусоргського. «Дзвін прорізає музичну тканину в моменти ідейно-стилістичних і драматургічних переломів, як, наприклад, у сцені коронації Бориса на царство, сцені галюцинацій Бориса (сцена з курантами) чи в завершальній, фінальній сцені опери - сцені з Юродивим. Мусоргський трактує дзвін полісемантично. Знаково багатозначна семантика дзвону формується ситуаційним, драматургічним, композиційним контекстами» $[8$, с. 6].

Показово, що подібне глибинне сприйняття символіки дзвону композитор співвідносив не тільки з образом Бориса Годунова, а й із власною долею та високою пам'яттю про своїх видатних сучасників, у тому числі Ф. Достоєвського, творчість якого він дуже цінував. Згідно з матеріалами дослідження I. Лапшина, будучи присутнім на пам'ятному літературному зібранні у зв'язку зі смертю великого письменника, «Мусоргський сів за рояль і зімпровізував похоронний дзвін, на кшталт того, який лунає в останній сцені «Бориса». Це був передостанній публічний виступ Мусоргського, а музична імпровізація - його останнім «вибач» не тільки покійному співцеві «принижених і ображених», а у усім живим» [7, с. $321-322]$.

Творчі заповіти великого російського композитора та духовно-етичні настанови його героїв виявилися актуальними й для багатьох митців XX століття, у тому числі й для А. Тарковського, для якого настанова Данили Заточника «не зри внешняя моя, но воззри внутренняя моя» стала своєрідним духовно-творчим кредо та визначила поетику його кінематографу [11, с. 37]. За влучним спостереженням С. Загребіна, «у фільмах Тарковського досліджується моральна природа людини, в основі якої - совість як сутність морального переживання й сором як усвідомлення духовної недосконалості» [5, с. 276]. Така проблематика обумовлює органічне поєд- 
нання в його творах минулого, сьогодення та майбутнього, що також має аналогії з базовим творчим методом М. Мусоргського («бий у минулому сьогоднішнє...»).

Досвід утілення духовно-історичних констант російського образу світу та культури, представлений у картині «Андрій Рубльов», А. Тарковський також зумів реалізувати в постановці опери «Борис Годунов», що здійснена в 1983 році на сцені Лондонського театру «Коверт-Гарден». Сценографом вистави став художник М. Двигубський, який працював з А. Тарковським над фільмом «Дзеркало», а художником по світлу - Роберт Брайн. За диригентським пультом стояв маестро Клаудіо Аббадо, а партію Бориса блискуче виконав Роберт Ллойд.

В інтерв’ю кореспонденту газети «Таймс» у 1983 році А. Тарковський сказав: «Мене займає головним чином внутрішня драма самого Бориса, і я думаю, що якщо б я знімав цю оперу, то фільм вийшов би камерний, інтимний. У центрі «Бориса2 проблема не влади, а людини, зломленої владою» [1]. Звертаючись до другої редакції опери М. Мусоргського, режисер тем не менше в сценічній версії вдало поєднав смислові «акценти» різноманітних версій цього твору, усе ж приділяючи першорядну увагу розкриттю глибини духовних страждань Бориса. Показово, що в цій виставі А. Тарковський повністю відмовився від завіси. «Перехід від однієї картини до іншої відзначався простим затемненням, і вся дія спектаклю розгорталася в одній декорації, яка, однак, завдяки висвітленню й декільком скупим і точним деталям набувала щоразу мовби новий обрис, нове смислове значення» [16, с. 309]. У кінцевому підсумку вистава набула сенсу не тільки спектаклю «для слухання», а й візуального видовища, що втілило найбільш показові кінематографічні прийоми-символи А. Тарковського, відомі в його попередніх роботах.

Ю. Анохіна в рецензії на спектакль констатує, що авторські символи, уведені А. Тарковським у цю сценічну версію, надали особливу оригінальність і метафізичну глибину цій постановці, викликаючи певні паралелі з філософським релігійно-етичним кінематографом російського режисера. «Перший відомий символ - ікона Трійці, спроектована на сценічний задник. Явище Трійці, вихопленої з темряви світловим променем-«камерою», глядач спостерігав у ту хвилину, 
коли диявол входив у душу ченця Григорія і той скидав із себе чернече вбрання, щоб змінити його на одяг Самозванця. Подібне явище спостерігалося й наприкінці вистави, коли народ, утомлений від пекельних оргій і бунту, забувався важким сном, а Юродивий, як неприкаяний, тинявся по сцені. У цю хвилину на «задньому плані» з'являлася фігура ангела, що пересувався над землею. I бачив іiі тільки Юродивий. Тут, як і у фільмі «Андрій Рубльов», божественна краса i сяйво сакрального світу відкривалися чистим серцем людям у годину великої скорботи і лих, зміцнюючи дух і рятуючи душу заплаканої Русі» [1].

Другий символ, який А. Тарковський уводить у спектакль, - маятник, який розгойдувався в арці, відраховуючи час, що залишився злочинному царю, і завмирав у момент його смерті. Прообраз цього маятника, за свідченням кінознавців, знаходимо в тому ж фільмі «Андрій Рубльов», у кінці сцени розправи над Патрикеєм.

Третій, найбільш знаковий, символ цієї постановки, на думку рецензента, - «величезна мапа Росії у вигляді килима, знахідка А. Тарковського, зазначена всіма рецензентами. Цей єдиний «декоративний» елемент «натякає» на царський терем, у якому розгортається дія. Карта-килим - це «простір Царьов», куди не сміють ступити ні мамка царівни, ні виверткий Шуйський, і тільки цар із дітьми вільно й безперешкодно проходять по ньому» [1].

Досить оригінальним є також трактування образу Юродивого (у спектаклі А. Тарковського його роль виконував Патрік Пауер), якого сам режисер характеризував так: «Він схожий на Мишкіна й Дон Кіхота. Він теж самотній, і його завдання - акцентувати помилковість шляху, яким ідуть люди» [16, с. 311]. При подібному підході очевидним є співвідношення цього персонажа зі знаковими фігурами світової літератури, що сходили не тільки до спадщини Ф. Достоєвського, а й до представників ренесансної епохи. Водночас А. Тарковський уносить у його тлумачення власний авторський «штрих», представляючи його сліпим. Герой протягом усієї вистави з'являється з мішком на голові. «Юродивий сліпий, але він прозріває горній світ, йому відкривається те, що приховано від інших» [1]. Ця смислова деталь трактовки одного з головних персонажів спектаклю принципово відрізняє його від трактовки О. Пушкіним та М. Мусоргським. 
У двох останніх авторів «Юродивий прозрівав насамперед суть земних речей, виводячи перед «народні очі» таємниці механізму злочинів, що творилися за високими царськими стінами: «не можна молитися за царя Ірода». У Тарковського Юродивий змушує згадати «Сліпих» Брейгеля - він прозріває не так суть земних речей, які завжди тяжкі, дріб'язкові, грубі, а вищого й останнього, Суддю і Спасителя» [16, с. 312], що, додамо, власне й виявляє не тільки християнські етичні настанови оперного шедевру М. Мусоргського, a і його актуальність у духовно-історичних реаліях культури кінця XX століття.

Висновки. «Борис Годунов» М. Мусоргського являє собою унікальний твір європейського музичного театру XIX століття. Численні авторські та постановочні редакції твору, активно затребувані в сучасній виконавській практиці, виявляють послідовний рух авторської музично-драматургічної думки від «моноопери» до «історичної народної музичної драми», а також органічність взаємодії позначених жанрових компонентів поетики названого твору. Водночас образно-семантична специфіка опери базується на духовно-релігійних, «храмових» константах, які становлять грунт російської музичної класики, що виявляється й у місцях розгортання оповідання, зосереджених на прихрамовій території, і на суттєвій драматургічній ролі персонажів, причетних до агіографічної традиції (царевич Димитрій, Пимен) і вищих проявів національної релігійності й духовності (Юродивий), і в затребуваності в поетиці твору семантики молитви, дзвону, що виявляють літургійно-містеріальний контекст як образу Бориса Годунова, так i поетико-інтонаційних особливостей опери М. Мусоргського загалом як «драми совісті» (Н. Тетеріна). Позначений духовно-релігійний контекст виявився затребуваним в історичному бутті твору в кінці XX століття, а також співвідносним із духовно-естетичними настановами творчості А. Тарковського. Його режисерська концепція постановки опери М. Мусоргського формувалася на перетині засвоєння духовних констант російської культури та їх творчого переосмислення. Останнє позначилося на доповненні символічного «ряду» твору семантичними ознаками ікони «Трійця», маятника, мапи Росії, а також на духовному поглибленні образу Юродивого. 


\section{СПИСОК ЛІТЕРАТУРИ}

1. Анохина Ю. Два «Бориса» (о постановке оперы М. Мусоргского Андреем Тарковским и Александром Сокуровым). URL: http://tarkovskiy.su/texty/analitika/Anohina2.html (дата обращения: 04.08.2020).

2. Берченко Р.Э. Композиторская режиссура М.П. Мусоргского. Москва : Едиториал УРСС, 2003. 221 с.

3. Гура И.С. М.П. Мусоргский: метафизика трагедийности : дисс. ... канд. искусствоведения: 17.00 .02 / Красноярская государственная академия музыки и театра. Красноярск, 2003. URL: dslib.net (дата обращения: 30.07.2020).

4. Жуйкова Л. Музыкальная эстетика М.П. Мусоргского. Научное издание. Санкт-Петербург : Композитор, 2015. 216 с.

5. Загребин С.С. Этика Тарковского. Челябинск : ООО «Работа плюс», 2012. 307 с.

6. Зорилова Л.С. О работе Федора Ивановича Шаляпина над образом Бориса Годунова. Вестник АХИ. 2017. № 8. С. 83-92.

7. Лапшин И. Модест Петрович Мусоргский. Звучащие смыслы. Альманах. Санкт-Петербург : Издательство Санкт-Петербургского университета, 2007. С. 275-332.

8. Луніна А. Храмова константа в «Борисі Годунові» М. П. Мусоргського. Мистецтвознавство України. Київ : Фенікс, 2012. Вип. 12. C. $96-108$.

9. Михайлова Е. «Борис Годунов» М. П. Мусоргского в редакции 1869 года: Истоки концепции. Драматургия. Слово в опере : автореф. дисс. ... канд. искусствоведения : 17.00.02 «Музыкальное искусство» / Санкт-Петербургская государственная консерватория (академия) им. Н.А. Римского-Корсакова. Санкт-Петербург, 2012. $25 \mathrm{c}$.

10. Михайлова Е. Христианская идея и молитва: Первая редакция «Бориса Годунова». Музыкальная академия. 2011. № 2. С. 32-37.

11. Нехорошев Л. «Андрей Рублев»: спасение души. Мир и фильмы Андрея Тарковского / сост. А.М. Сандлер. Москва : Искусство, 1990. C. $37-64$.

12. Павлинова В.П. Музыкальные драмы М. П. Мусоргского в свете русских литургических и античных театральных координат. Вестник ПСТГУ. Серия V «Вопросы теории и истории христианского искусства». 2019. Вып. 33. С. 114-133.

13. Протопопов В. Образ Бориса Годунова в опере Мусоргского. Советская музыка. 1939. № 4. С. 34-48.

14. Сабинина М. М.П. Мусоргский. История русской музыки : в 10 т. Москва : Музыка, 1994. Т. 7 : 70-80-е годы XIX века. Ч. 1. C. $210-286$.

15. Серегина Н. Прославление Богородицы во Вступлении к опере «Хованщина» М.П. Мусоргского. М.П. Мусоргский: Истоки. Истина. Искусство : сборник статей и материалов Международной научной конференции, посвященной 175-летию со дня рождения 
М. П. Мусоргского (5-6 апреля 2014 г.). Санкт-Петербург ; Великие Луки : Российский институт истории искусств, 2015. Вып. 1. C. $66-75$.

16. Суркова О. «Борис Годунов» - постановка Андрея Тарковского. Мир и фильмы Андрея Тарковского / сост. А.М. Сандлер. Москва : Искусство, 1990. С. 309-313.

17. Татарнікова А.А. Містеріально-славословні аспекти французького музичного театру початку XX століття (на прикладі «Жонглера Богоматері» Ж. Массне). Українська культура: минуле, сучасне, шляхи розвитку (напрям: «Мистецтвознавство») : науковий збірник. 2020. Вип. 32. С. 72-78.

18. Тетерина Н.И. Историзм художественного мышления М.П. Мусоргского (от источниковедения и текстологии к драматургическим концепциям и философии истории) : автореф. дисс. ... канд. искусствоведения : 17.00.02 / Государственный институт искусствознания. Москва, 2007. 43 с.

19. Хубов Г. Н. Мусоргский. Москва : Музыка, 1969. 804 с.

\section{REFERENCES}

1. Anokhina, Yu. (2020). Two «Boris» (about the production of M. Mussorgsky's opera by Andrei Tarkovsky and Alexander Sokurov). Retrieved from http://tarkovskiy.su/texty/analitika/Anohina2.html.

2. Berchenko, R. E. (2003). Composer direction by M.P. Mussorgsky. Moscow : Editorial URSS [in Russian].

3. Gura, I. S. (2003). M. P. Mussorgsky: The Metaphysics of Tragedy. Candidate's thesis. Krasnoyarsk: Krasnoyarskaya gosudarstvennaya akademiya muzyki i teatra. Retrieved from dslib.net.

4. Zhuykova, L. (2015). Musical aesthetics of M. P. Mussorgsky. Scientific publication. St. Petersburg: Kompozitor [in Russian].

5. Zagrebin, S. S. (2012). Ethics of Tarkovsky. Chelyabinsk: OOO «Rabota plyus» [in Russian].

6. Zorilova, L. S. (2017). On the work of Fyodor Ivanovich Chaliapin on the image of Boris Godunov. Vestnik AKHI, 8, pp. 83-92 [in Russian].

7. Lapshin, I. (2007). Modest Petrovich Mussorgsky. Zvuchashchiye smysly. Al'manakh. St. Petersburg : Izdatel'stvo Sankt-Peterburgskogo universiteta, pp. 275-332 [in Russian].

8. Lunina, A. (2012). Temple constant in «Boris Godunov» by M. P. Mussorgsky. Mystetstvoznavstvo Ukrayiny, 12, pp. 96-108 [in Ukrainian].

9. Mykhaylova, E. (2012). «Boris Godunov» by M. P. Mussorgsky in the edition of 1869: The origins of the concept. Dramaturgy. The word in the opera. Extended abstract of candidate's thesis. St. Petersburg : Sankt-Peterburgskaya gosudarstvennaya konservatoriya (akademiya) im. N. A. Rimskogo-Korsakova [in Russian].

10. Mykhaylova, E. (2011). Christian Idea and Prayer: First Edition of «Boris Godunov». Muzykal'naya akademiya, 2, pp. 32-37 [in Russian]. 
11. Nekhoroshev, L. (1990). «Andrei Rublev»: the salvation of the soul. Mir i fil'my Andreya Tarkovskogo. Moscow : Iskusstvo, pp. 37-64 [in Russian].

12. Pavlinova, V. P. (2019). Musical dramas by M.P. Mussorgsky in the light of Russian liturgical and antique theatrical coordinates. Vestnik PSTGU. Seriya V: Voprosy teorii $i$ istorii khristianskogo iskusstva, 33, pp. 114-133 [in Russian].

13. Protopopov, V. (1939). The image of Boris Godunov in Mussorgsky's opera. Sovetskaya muzyka, 4, pp. 34-48 [in Russian].

14. Sabinina, M. (1994). M. P. Mussorgsky. Istoriya russkoy muzyki: v $10 t$, 7, pp. 210-286 [in Russian].

15. Seregina, N. (2015). Glorification of the Mother of God in the Introduction to the opera «Khovanshchina» by M. P. Mussorgsky. M. P. Musorgskiy: Istoki. Istina. Iskusstvo : Sb. statey $i$ materialov Mezhdunarodnoy nauchnoy konferentsii, posvyashchennoy 175-letiyu so dnya rozhdeniya M. P. Musorgskogo (5-6 aprelya 2014 g.). St. Petersburg; Velikie Luki : Rossiyskiy institut istorii isusstv, 1, pp. 66-75 [in Russian].

16. Surkova, O. (1990). Boris Godunov - production by Andrei Tarkovsky. Mir i fil'my Andreya Tarkovskogo. Moscow: Iskusstvo, pp. 309-313 [in Russian].

17. Tatarnikova, A. A. (2020). Mysterial-praise aspects of the French musical theater on the ear of the XX century (on the butt of «The Juggler of the Mother of God» by J. Massenet). Ukrayins'ka kul'tura: mynule, suchasne, shlyakhy rozvytku (napryam: «Mystetstvoznavstvo»): nauk. zbirnyk, 32, pp. 72-78 [in Ukrainian].

18. Teteryna, N. Y. (2007). Historicism of M. P. Mussorgsky's artistic thinking (from source studies and textology to dramatic concepts and philosophy of history). Extended abstract of candidate's thesis. Moscow: Gosudarstvennyy institut iskusstvoznaniya [in Russian].

19. Khubov, G. N. (1969). Mussorgsky. Moscow: Muzyka [in Russian]. 